\title{
Body size characteristics and polymorphism in GH and GHRH genes of Simeulue Buffalo of Aceh, Indonesia
}

\author{
KARTINI ERIANI ${ }^{1, \bullet}$, RAHMI RAHMI $^{2}$, IKHWAN JAMIL ${ }^{3}$, ROSNIZAR ROSNIZAR $^{1}$, AL AZHAR ${ }^{4}$ \\ ${ }^{1}$ Departement of Biology, Faculty of Mathematics and Natural Sciences, Universitas Syiah Kuala. Jl. Syech Abdurrauf No. 3, Darussalam, Banda Aceh \\ 23111, Aceh, Indonesia. Tel.: +62-651-7552291, Fax.: +62-651-7552291, •email: kartini_eriani@unsyiah.ac.id, kartini.eriani@gmail.com \\ ${ }^{2}$ Master Program of Biology, Faculty of Mathematics and Natural Sciences, Universitas Syiah Kuala. Jl. Syech Abdurrauf No. 3, Darussalam, Banda \\ Aceh 23111, Aceh, Indonesia. \\ ${ }^{3}$ Holticulture, Livestock and Animal Health Office of Simeulue. Sinabang, Simeuleu Timur, Simeulue 23891, Aceh, Indonesia \\ ${ }^{4}$ Faculty of Veterinary Medicine, Universitas Syiah Kuala. Jl. Tgk. Hasan Krueng Kalee No. 4, Darussalam, Banda Aceh 23111, Aceh, Indonesia
}

Manuscript received: 8 October 2018. Revision accepted: 24 December 2018

\begin{abstract}
Eriani K, Rahmi R, Jamil I, Rosnizar R, Azhar A. 2019. Body size characteristics and polymorphism in GH and GHRH genes of Simeulue Buffalo of Aceh, Indonesia. Biodiversitas 20: 236-242. This study was done to determine body size characteristics, to identify the presence of polymorphism in the GH/MspI and GHRH/HaeIII genes, and to analyze the relationship between GH and GHRH gene polymorphisms to body size characteristics in Simeulue buffalo. Experimental animals used were 45 Simeulue buffalo randomly sampled from three subdistricts, i.e., Salang, Alafan and Simeulue Cut, fifteen from each subdistrict. Body size characteristics measured were withered height, body length, chest circumference, chest depth, and hip height. A $5 \mathrm{~mL}$ whole blood was collected from fifteen out of forty five by using EDTA as an anticoagulant. Extraction of genomic DNA and analysis of GH/MspI and GHRH/HaeIII polymorphisms was done using GeneAid DNA extraction kit and polymerase chain reaction-restriction length fragment polymorphism (PCR-RFLP) method, respectively. The data of body size characteristics which includes mean value, standard deviation, and coefficient of variation were analyzed descriptively. The molecular data represented by DNA banding pattern was used to calculate allele and genotype frequencies, expected (He) and observed (Ho) heterozygosities, and Hardy-Weinberg equilibrium. The relationship between genotype and body size characteristic was analyzed using t-test. The results showed that coefficient of variation in body size characteristics was low, ranging from 5.39-16.06\% in the age category of 4-6 years old and ranging from 5.25-11.27\% in the age category of 2- 4 years old. The results of the molecular analysis indicated that $\mathrm{GH} / \mathrm{MspI}$ locus was monomorphic by the presence of one (+/+) genotype. GHRH/Hae III locus was polymorphic as shown by the presence of 3 genotypes namely AA (0.13), AB (0.80) and BB (0.07). Expected heterozygosity $(0.80)$ was higher than observed heterozygosity (0.49). The frequency of GHRH/HaeIII agreed with Hardy Weinberg equilibrium. GHRH/Hae III polymorphism did not significantly influence $(\mathrm{P}>0.05)$ body size characteristics of Simeulue buffalo.
\end{abstract}

Keywords: Bubalus bubalis, GH/MspI, GHRH/HaeIII, PCR RFLP, polymorphism, Simeulue

\section{INTRODUCTION}

Simeulue buffalo belongs to the national buffalo breed which is part of the genetic biodiversity of Indonesian noncattle meat-producing animals (Suswono 2014). Considering the geographical conditions of Simeulue district with a large number of swamps suitable for buffalo habitat, it is appropriate to choose Simeulue Buffalo as local meat-producing livestock instead of cattle. In attempts to increase the buffalo productivity, it is necessary to improve rearing management, cross-breeding, and animal selection as well as developing genetic resources baseline through the characterization of genetic diversity.

Until recently, research on Simeulue buffalo which concerned in genetic studies has only been carried out by Sari (2014). The study revealed that Simeulue buffalo had a close relationship with Riau buffalo and they situated in a separate cluster from Aceh buffalo in Central Aceh and Aceh Besar. However, the information focusing on gene diversity especially growth genes polymorphism of Simeulue buffalo has remained unexplored. This data is critically important as a reference for improving the genetic quality of Simeulue buffalo in the next future. Genetic diversity study can be done through analysis of structural genes or other genes that play a significant role in cattle growth. Two important genes that previously known affecting the growth of buffalo are growth hormone (GH) and growth hormone releasing hormone $(\mathrm{GHRH})$ genes. The two genes are responsible for controlling the buffalo growth properties, and their polymorphism is important in supporting many selection programs of their growth. Previous studies have revealed that there are polymorphisms in these genes especially at $\mathrm{GH} / M s p 1$ and GHRH/Hae 111 loci in Banten buffalo (Diyono et al. 2010; Sutarno 2010).

Polymerase chain reaction-restriction fragment length polymorphism (PCR-RFLP) is a method to determine the presence of polymorphisms in a gene. This method begins with the amplification of a particular DNA fragment. The fragments are then cut by restriction enzyme that recognizes the specific sites of the DNA. The restriction enzyme is a protein isolated from bacteria (Guidry and Gahn 2012). This study aimed to obtain information about the quantitative characteristics of Simeulue buffalo body size including body length, whiter height, chest circumference, chest depth, and hip height. Furthermore, it 
also intended to identify polymorphism of $\mathrm{GH} / M \operatorname{sp} 1$ and GHRH/Hae111 gene fragments in Simeulue buffalo population, and to analyze the relationship between body size characteristics with GH/Msp1 and GHRH/Hae 111 polymorphisms in Simeulue buffalo.

\section{MATERIALS AND METHODS}

\section{Study area}

The research was conducted in the field and laboratory. In the field, we chose three sub-districts, i.e., Salang, Alafan, and Simeulue Cut of Simeulue District, Aceh Province, Indonesia for sampling and measurements of buffalo body size. The molecular analysis was conducted in Research Laboratory, Faculty of Veterinary Medicine, Syiah Kuala University, Banda Aceh, Indonesia.

\section{Procedures}

Field sampling and blood sample collection

Locations and sampling technique followed the purposive sampling method. The research was conducted in 3 sub-districts namely Salang, Simeulue Cut, and Alafan. A total of 45 Simeulue buffaloes collected from three subdistricts for measurement their body size characteristics. The buffalo samples were grouped into two age categories, 4-6 and 2-4 years with criteria according to Lestari et al. (2018). Blood sampling was carried out by collecting about $3 \mathrm{~mL}$ of blood samples from buffalo through the jugular vein using a venoject and vacutainer tubes with EDTA and then stored at $4^{\circ} \mathrm{C}$.

\section{Body size characteristics measurement}

All phenotypic characters which included whither height, body length, chest circumference, chest depth, and hip height were measured in $\mathrm{cm}$ unit using a measuring tape or stick scale. The technical measurement methods followed the procedure of Diyono et al. (2010): the whiter height was measured from the ground to the highest point of the shoulder (scapula). Body length was measured from the shoulder joint (humerus) to the sitting bone (tuber ischii). Chest circumference was measured by a circular chest cavity behind the shoulder joint (os scapula) in the chest measured from the highest point of the shoulder and sternum. Hip height was measured from the highest point of the hip perpendicular to the ground.

\section{DNA extraction}

Genomic DNA was isolated and purified from $3 \mathrm{~mL}$ blood samples taken from 15 buffaloes ( 5 from each subdistrict using DNA extraction kits (Geneaid) which include $\mathrm{K}$ proteinase, absolute ethanol, lysis buffer, $\mathrm{A}$ and $\mathrm{B}$ wash buffer. The step by step technical work followed the extraction protocol provided by the kit. Furthermore, the quality of extraction was seen by electrophoresis.

\section{PCR gene amplification}

The PCR reaction was carried out with a total volume of $25 \mu \mathrm{L}$ of the solution mixture consisting of $12.5 \mu \mathrm{L}$ PCR mix (buffer, dNTP mix, Taq DNA polymerase enzyme), 3 $\mu \mathrm{L}$ reverse and forward primer $(\mathrm{GH} / M s p \mathrm{I}$ and GHRH/HaeIII gene primers), $4 \mu \mathrm{L}$ DNA mold and $2.5 \mu \mathrm{l}$ sterile $\mathrm{dH}_{2} \mathrm{O}$. The $\mathrm{PCR}$ reaction conditions in a thermocycler machine are designed with a temperature of $94^{\circ} \mathrm{C}$ for 4 minutes, then 30 reaction cycles consisting of denaturation $94^{\circ} \mathrm{C}$ for 10 seconds, annealing (primer specific temperature) for 1 minute, extension of $72^{\circ} \mathrm{C}$ for 2 minutes. A final extension at $72^{\circ} \mathrm{C}$ for 7 minutes. The temperature of annealing for primary $\mathrm{GH} / M s p 1$ and $\mathrm{GHRH} / \mathrm{Hae}$ III locus is $45^{\circ} \mathrm{C}$ and $60^{\circ} \mathrm{C}$.

\section{Genotyping and visualizing DNA bands by PCR-RFLP technique}

The PCR product of gene amplification was cut with two restriction enzymes, MspI and HaeIII, that recognizes the $C^{*} \mathrm{CGG}$ restriction site in the $\mathrm{GH}$ gene and the $\mathrm{GG}^{*} \mathrm{CC}$ site in the GHRH gene. The cutting procedure followed the instruction of the enzyme, which is for each $1.5 \mathrm{~mL}$ tube filled with $50 \mu \mathrm{L}$ solution containing $\mathrm{H}_{2} \mathrm{O}(42 \mu \mathrm{L}), \mathrm{EB} / \mathrm{AW}$ buffer $(5 \mu \mathrm{L})$, DNA from PCR $(2.5 \mu \mathrm{L})$ and enzymes restriction $(0.5 \mu \mathrm{L})$. The test tube was incubated at $37^{\circ} \mathrm{C}$ for 4 hours and stopped by heating at $70{ }^{\circ} \mathrm{C}$ for 15 minutes. The restricted DNA band pattern was visualized using $2 \%$ agarose gel electrophoresis. A total of $3 \mu \mathrm{L}$ of the restriction product were mixed with $7 \mu \mathrm{L}$ DNA loading dye $(0.01 \%$ bromthymol blue, xylene cyanol 0.01 and $50 \%$ glycerol) and carefully inserted into the gel well. Electrophoresis is carried out at a constant voltage of 80 volts for 90 minutes - visualization of the results of gel electrophoresis with DNA imager (Bio-Rad, USA).

\section{Data analysis}

Measurement of body size characteristics

The analyzed of the buffalo body size data including their mean value, standard deviation, and coefficient of variation used descriptive statistic.

$$
\begin{aligned}
& \bar{x}=\frac{\sum_{i=l}^{n} x_{i}}{n} \\
& s=\sqrt{\frac{\sum_{i=l}^{n} x_{i}^{2}-\left(\sum_{i=l}^{n} x_{i}\right)^{2} / n}{n-1}} \\
& C V=\frac{s}{\bar{x}} \times 100 \% \quad S E=\frac{s}{\sqrt{n}}
\end{aligned}
$$

Where :

$$
\begin{array}{ll}
\bar{x} & =\text { mean value } \\
x_{i} & =\text { each data value } \\
\mathrm{n} & =\text { the number of samples in the population } \\
\mathrm{CV} & =\text { Coefficient of variation } \\
\mathrm{SE} & =\text { standard error } \\
\mathrm{S} & =\text { standard deviation }
\end{array}
$$

\section{Identification of polymorphism}

The molecular data of the GH/Msp1 and GHRH/Haelll loci in Simeulue buffalo population were analyzed in term allele frequency, the observed and expected values of heterozygosity, and the Hardy-Weinberg equilibrium. 
Allele frequency for each locus was calculated according to the formula by Nei (1987):

$$
x_{i} \frac{\left(2 n_{i i}+\sum_{j \neq i} n_{i j}\right)}{2 n}
$$

Where:

$x_{i}=$ Allele frequency

$n_{i i}=$ The number of the genotype of allele at- $\mathrm{i}$

$n_{i j}=$ The number of allele at-i linkage to an allele at $\mathrm{j}(\mathrm{j} \neq \mathrm{i})$

The Hardy-Weinberg equilibrium was analyzed by the chi-square $(\chi 2)$ test according to Hartl (1988), as shown below:

$$
\chi^{2}=\sum_{i \neq j} \frac{(O b s-E x p)^{2}}{E x p}
$$

Where:

$\chi^{2}=$ The value of chi-square

Obs $=$ The number of observed genotype at $\mathrm{i}$

$\operatorname{Exp}=$ The number of expected genotype at-i

The value of Ho dan He was determined by the formula: The value of observed of heterozygosity (Ho)

$$
H_{\circ}=\sum_{i \neq j} \frac{N_{1} i j}{N}
$$

Where:

$H_{o}=$ Observed heterozygosity

$H_{l i j}=$ The number of heterozygote individual at locus 1

$\mathrm{N}=$ The total number of individuals observed

The value of expected of heterozygosity $(\mathrm{He})$

$$
\begin{aligned}
H e & =2 \mathrm{AB} \\
& =2 \frac{16}{30} x \frac{14}{30} \\
& =2(0.5333)(0.46667) \\
& =0.4978
\end{aligned}
$$

Where:

$$
\begin{aligned}
& \mathrm{He}=\text { Expected heterozygosity } \\
& \mathrm{A}=\text { The Frequency of allele A } \\
& \mathrm{B}=\text { The Frequency of allele } \mathrm{B}
\end{aligned}
$$

The relationship between gene polymorphism and body size was calculated as follow:

$$
\mathrm{t}=\frac{x_{1}-x_{2}}{\sqrt{\frac{s_{1}^{2}}{n 1}+\frac{s_{2}^{2}}{n 2}}}
$$

Where:

$\mathrm{t}_{\mathrm{h}}=\mathrm{t}$-test value

$\mathrm{x}_{1}=$ Mean value of sample from the $1^{\text {st }}$ population

$\mathrm{x}_{2}=$ Mean value of sample from the $2^{\text {nd }}$ population

$\mathrm{s}_{1}=$ Standard deviation of sample from the $1^{\text {st }}$ population

$\mathrm{s}_{2}=$ Standard deviation of sample from the $2^{\text {nd }}$ population

$\mathrm{n} 1=$ Number of sample from $1^{\text {st }}$ population

$\mathrm{n} 2=$ Number of sample from $2^{\text {nd }}$ population

\section{RESULTS AND DISCUSSION}

\section{Body size characteristics of Simeulue buffaloes}

The coefficient of variation of body size of buffaloes sampled from three sub-districts namely Salang, Simeulue Cut, and Alafan were small, ranging from 5.39-16.06\% and from $5.25-11.27 \%$ for the for the category of age 4-6 years old and 2-4 years old, respectively (Table 1). The possible reason for the low variation among the three populations is due to the position of these sites on the same island so that they have a typical environmental characteristic. Environmental factors such as optimal temperature and humidity will be good for livestock growth. If the temperature and humidity are appropriate, it will increase the appetite of the buffalo so that the amount of feed consumed is high. Also, feeding factors and rearing management also influence the growth of buffalo livestock (Diyono et al. 2010).

\section{Amplification and genotyping of GH/Msp1 locus}

PCR technique with a specific pair of primers has successfully amplified the GH gene along $327 \mathrm{bp}$ from Simeulue buffaloes blood DNA extract. The quality of the amplification of the GH/MspI locus was visualized as bands on agarose gel electrophoresis (Figures 1 and 2).

PCR-DNA amplification using a specific primer pair has successfully amplified the 327 bp $\mathrm{GH}$ gene from Simeulue buffalo blood-DNA extracts. The result confirmed a previous work by Diyono et al. (2010) that can amplify the GH/MspI fragment gene around $327 \mathrm{bp}$ in his work on Banten buffalo population. The total $\mathrm{GH}$ gene in Buffalo has a length about $1800 \mathrm{bp}$ consisting of five exons and four introns. The GH/Msp 1 gene fragment is found in non-coding regions (introns) (Jakaria and Noor 2011).

The RFLP results of the GH gene using MspI restriction enzymes showed that there was no polymorphism along the $327 \mathrm{bp}$ of the amplified locus. The result also revealed that the MspI locus as single genotype $(+/+)$ because of all fragments were completely cut at the same restriction site resulting two similar fragments length at $227 \mathrm{bp}$ and 100 bp. If among individuals have differences in their DNA sequences at specific restriction sites (polymorphism), then the restriction enzymes will cut their DNA into fragments of different lengths. Another possible polymorphism may occur If a portion of the sample is only cut at a single locus and another sample is cut at two or more loci.

These results strongly indicated that the MspI locus in the GH gene is monomorphic. Monomorphic means that in a gene population there is only one type of allele (not diverse). This situation was not far with the results of Putra et al. (2014) in his research on Aceh cattle that the $\mathrm{GH} /$ Msp1 locus was monomorphic. However, different results were reported by Diyono et al. (2010) in Banten buffalo which stated that the $\mathrm{GH} / M s p \mathrm{I}$ locus was polymorphic because of a $\mathrm{C}$-T point mutation occurred at the position of-104 in intron 3. Polymorphic means that in a population of there are two or more alleles in a specific locus of a gene (genes are diverse). 
Table 1. Body size characteristics among female Simeulue buffaloes sampled from three sub-district: Alafan, Salang and Simeulue Cut in two age-clusters

\begin{tabular}{lcccc}
\hline \multirow{2}{*}{ Body size } & \multicolumn{2}{c}{ Aged 2 to 4 years old } & \multicolumn{2}{c}{ Aged 4 to 6 years old } \\
\cline { 2 - 5 } & $\mathbf{X}$ & $\mathbf{C V}(\boldsymbol{\%})$ & $\mathbf{x}$ & CV $(\%)$ \\
\hline & & & & \\
Body length & 106.37 & 7.88 & 124.75 & 16.06 \\
Withers height & 108.8 & 5.25 & 119.74 & 12.55 \\
Chest circumference & 159.2 & 11.27 & 168.12 & 5.39 \\
Chest depth & 61.42 & 9.57 & 71.79 & 12.95 \\
Hip height & 106.85 & 8.3 & 117.35 & 7.20 \\
& & & & \\
\hline
\end{tabular}

Note: $\mathrm{x}=$ mean value; $\mathrm{CV}=$ Coefficient of Variation

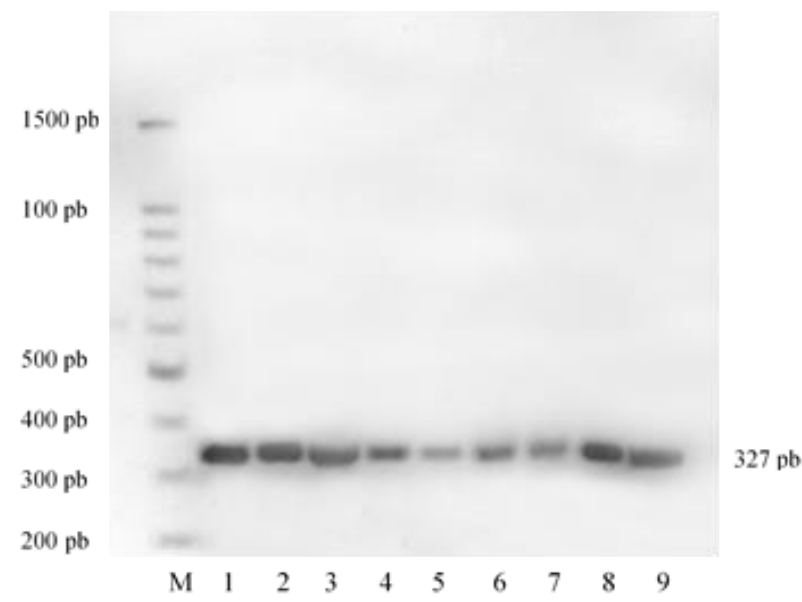

Figure 1. Representatives gel electrophoresis image showing DNA bands result from GH/Msp 1 gene amplification. Note: annealing temperature was $45^{\circ} \mathrm{C}$. $\mathrm{M}$ is DNA marker, and 1-9 indicated amplified DNA products

\section{Amplification and genotyping of GHRH/HaeIII fragments}

The annealing temperature of $60^{\circ} \mathrm{C}$ for 45 seconds had successfully amplified the GHRH/HaeIII gene along 451 bp (Figure 3). The procedure was slightly different with Jakaria et al. (2007) which used annealing temperature of $43^{\circ} \mathrm{C}$ for 45 seconds. The success of the amplification is very dependent on this primer attachment temperature on the target DNA and the concentration of PCR reagent material and the PCR machine. If the annealing temperature is not suitable, there is a high probability of mispriming (primer attachment at an undesirable place). Also, too low concentration of PCR reagent material such as $\mathrm{MgCl}_{2}$ can reduce $\mathrm{PCR}$ products, and if the concentration was too high it could produce an accumulation of nontargeted products so that the DNA bands produced are not specific (Handoyo and Rudiretna 2010). The result of amplification of a 451 bp GHRH/HaeIII DNA fragment agreed with previous results by Primasari et al. (2009) who successfully amplified a 451 bp GHRH/HaeIII DNA fragment in local buffaloes from several regions in Indonesia (Semarang, Mataram, Medan, and Banten).
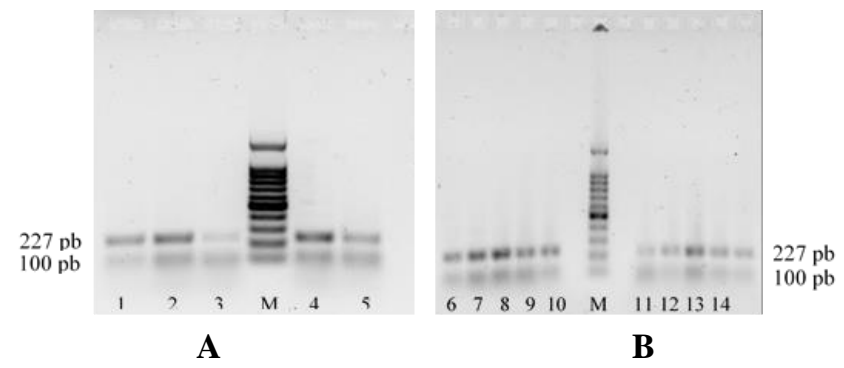

Figure 2. Representative of $1 \%$ agarose gel electrophoresis image of PCR-RFLP of GH/MspI genes. Note: $\mathrm{M}$ is a marker DNA; Number 1-5 in figure A and 6-15 in figure B were DNA from buffalo 1 to 15 , respectively

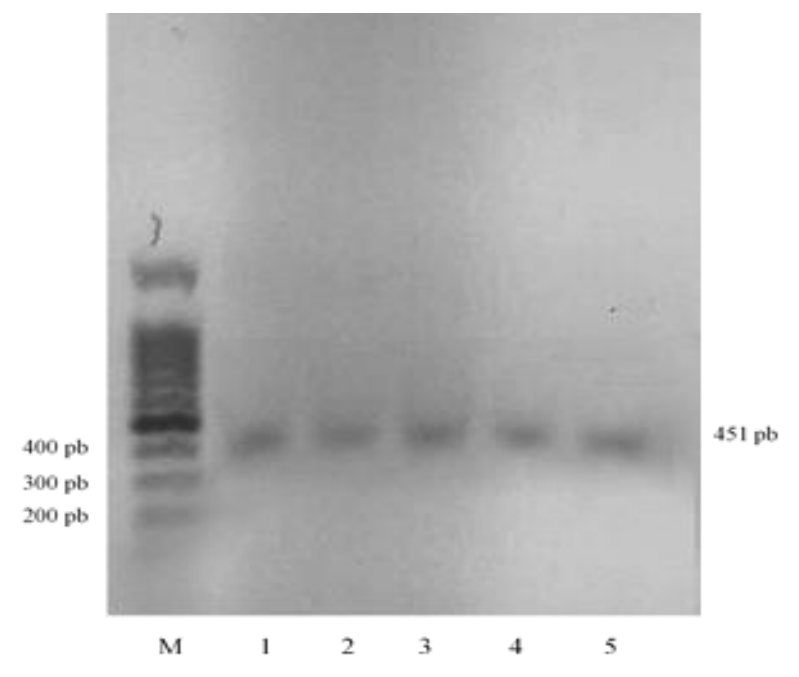

Figure 3. Gel electrophoresis image of GHRH gene amplification. Note: $\mathrm{M}$ is a marker, Number 1-5 represent DNA samples from buffalo number 1 to 5

Furthermore, every buffalo that has uncut 451 bp of GHRH gene indicating there is a mutation in the gene. Therefore, if the buffalo DNA samples have combined fragments, both the uncut mutated fragment and the remaining a cut non-mutated fragment, they are called heterozygous individuals (Jakaria et al. 2007). Mutations are changes in the sequence of DNA nucleotide bases due to spontaneous errors during the replication process or caused by a specific environmental agent that is able to change the bases. Gen mutations are a determinant for the emergence of genetic diversity than in turn results in diversity in life (Ruchlik et al. 1990).

\section{GH dan GHRH genes polymorphism}

Variation or polymorphism is characterized by the presence of two or more alleles in a population. The gene is polymorphic if the frequency of one of the alleles is less than $99 \%$. If it does not meet the criteria, the gene is monomorphic (Figures 4 and 5). Genetic diversity in a population can be used as a parameter in studying population genetics and evolution (Szatkowska et al. 2009; Konca and Akyuz 2017). In addition, it can also be used to identify and preserve individuals in the population associated with special characters. The level of variation in 
the population can be seen from the allele frequency (Tables 2 and 3). Allele frequency is the ratio of one allele relative to the overall allele found in one population. Information about the genetic diversity of a population using several loci can be explained by the value of heterozygosity (Nei and Kumar 2000).

In the $\mathrm{GH} / M s p 1$ gene fragment, only one genotype was found, namely $+/+$, so that the $M s p$ I fragment in Simeulue buffalo was assumed monomorphic. This result is in agreement with Putra et al. (2014) who showed the absence of a polymorphism in the GH/MspI gene in cattle populations in Aceh. The GHRH/HaeIII fragment, on the other hand, was polymorphic by the occurrence of $\mathrm{AA}, \mathrm{AB}$, and $\mathrm{BB}$ genotypes. et alThe results of study by Primasari et al. (2009) also indicated that the GHRH/HaeIII gene found in buffalo from four regions in Indonesia (Semarang, Mataram, Siborong-borong, and Banten) is polymorphic. However, Diyono et al. (2010), in his research on Banten's buffaloes found that there were polymorphisms both GH/MspI and GHRH/HaeIII loci.

The low genotypic diversity in Simeulue buffalo can be explained as the minimal number of males found in three sub-districts, i.e., Salang, Alafan and Simeulue Cut. The male individuals $20 \%$ was less than the female buffalo population. In addition, the mating occurred naturally so that the possibility of inbreeding occurs (mating with close relatives). High inbreeding in a population can reduce variation in this population because the gene flow only occurs in the same location so that its diversity is also reduced and can even lead to genetic diseases such as albino (Andreas et al. 2010).

\section{Hardy-Weinberg equilibrium}

The balance of genotype frequency in the $M s p \mathrm{I}$ fragments was not calculated because the number of allele frequencies was equal to one. The chi-square test $(\chi)$ on the genotype of the GHRH/Hae 111 fragment in Simeulue district showed that the fragment genotype frequency was in Hardy Weinberg's equilibrium. A population is said to be in Hardy Weinberg's equilibrium if the genotypic frequency (p2, 2pq, and q2) and allele frequency remain constant from one generation to the next generation. Carroll and Fox (2008) intended that the gene balance in the population occur in the absence of selection, mutation, migration and genetic drift.

Conversely, if there is a continuous genotype accumulation, divided population, mutation, selection, migration, and mate choice in the same population, the population will deviate from the balance of Hardy Weinberg. Genotypic frequency balance in GHRH/HaeIII gene fragments in Simeulue buffaloes can occur because of the Simeulue island, the place where the cattle lives, is an isolated island separated from other islands in Aceh, so there is lack of migration. The results of Sari et al. (2013) through mtDNA analysis on the D-Loop area showed that the Simeulue buffalo population was in a separate cluster from the Gayo buffalo and other local buffalo populations. At the GHRH/HaeIII locus, although mutations may occur, it does not affect the balance of the Simeulue buffalo population as a whole so that the population is still in Hardy Weinberg's equilibrium.

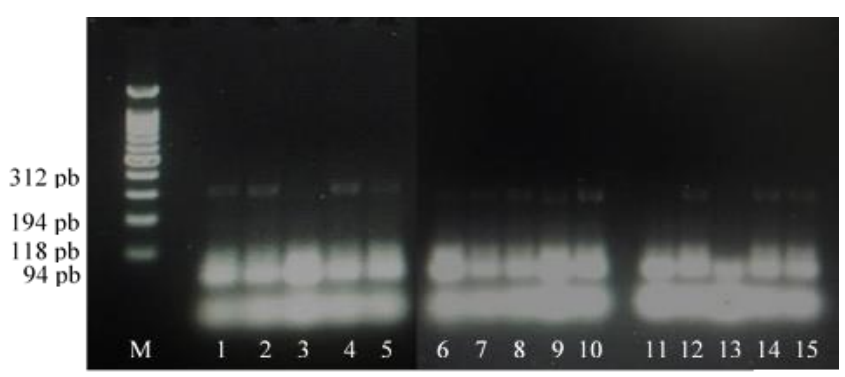

Figure 4. Gel electrophoresis image of PCR-RFLP GHRH/Hae 111 Simeulue Buffaloes gene. Note: $M$ is DNA ladder 100 bp. line 1,2,4,5, 6-10, and 12-15 were genotype AB (312 pb,194 pb, $118 \mathrm{pb}$ dan $94 \mathrm{pb}$ ), line 3 and 11 were genotype AA (194 pb, $118 \mathrm{pb}$ dan $94 \mathrm{pb}$ ) and line 13 was genotype BB (312 pb and $94 \mathrm{pb)}$

\begin{tabular}{|c|c|c|c|}
\hline $\mathbf{M}$ & AB & BB & $\mathbf{A A}$ \\
\hline \multicolumn{4}{|l|}{$500 \mathrm{pb}$} \\
\hline \multicolumn{4}{|l|}{$400 \mathrm{pb}$} \\
\hline & 312 & 312 & \\
\hline \multicolumn{4}{|l|}{$300 \mathrm{pb}$} \\
\hline \multicolumn{4}{|c|}{$200 \mathrm{pb}$} \\
\hline & 194 & & 194 \\
\hline & 118 & & 118 \\
\hline \multicolumn{4}{|l|}{$100 \mathrm{pb}$} \\
\hline & 94 & 94 & 94 \\
\hline
\end{tabular}

Figure 5. A representative diagram of PCR-RFLP GHRH/HaeIII

Table 2. Genotype frequency of GH/Msp1 dan GHRH/Hae III loci

\begin{tabular}{cccccc}
\hline $\mathbf{N}$ & \multicolumn{3}{c}{ Genotype } & \multicolumn{3}{c}{ Allele } \\
\hline \multirow{2}{*}{15} & $+/+$ & $-/-$ & $+/-$ & + & - \\
& 1,000 & 0,000 & 0,000 & 1,000 & 0,000 \\
\hline
\end{tabular}

Table 3. The allele frequency of GH/MspI and GHRH/HaeIII loci

\begin{tabular}{lccccc}
\hline $\mathbf{N}$ & \multicolumn{3}{c}{ Genotype } & \multicolumn{3}{c}{ Allele } \\
\hline \multirow{2}{*}{15} & $\mathrm{AA}$ & $\mathrm{BB}$ & $\mathrm{AB}$ & $\mathrm{A}$ & $\mathrm{B}$ \\
& 0.133 & 0.066 & 0.866 & 0.533 & 0.467 \\
\hline
\end{tabular}

\section{Heterogeneity value}

Genetic variation can be seen from the character of alleles in specific loci which are the expressions of the genes. Genetic diversity can be seen based on heterozygosity values (Table 4). The value of expected heterozygosity $(\mathrm{He})$ is an estimate of appropriate genetic diversity in livestock populations because the calculation is directly based on the frequency of alleles. The Ho and $\mathrm{He}$ values for the GH/HaeIII gene were 0.80 and 0.49 respectively. 
Table 4. Ho and $\mathrm{He}$ values of GH/HaeIII gene

\begin{tabular}{lllll}
\hline Species & Location & Total & Ho & He \\
\hline Buffalo & Simeulue & 15 & 0,80 & 0,49 \\
\hline
\end{tabular}

Table 5. Body size measurements (mean values + SD) of Simeulue Buffaloes with different genotypes

\begin{tabular}{lcc}
\hline \multirow{2}{*}{ Body Size } & \multicolumn{2}{c}{ Genotypes } \\
\cline { 2 - 3 } & $\mathbf{A B}$ & $\mathbf{B B}$ \\
\hline & $(\mathrm{n}=12)$ & $(\mathrm{n}=2)$ \\
Body length $(\mathrm{cm})$ & $106.75+11.82$ & $113.00+11.31$ \\
Withers height $(\mathrm{cm})$ & $111.25+6.63$ & $114.50+3.54$ \\
Chest circumference $(\mathrm{cm})$ & $161.75+17.17$ & $148.50+20.51$ \\
Chest depth $(\mathrm{cm})$ & $64.25+10.73$ & $64.50+10.61$ \\
Hip height $(\mathrm{cm})$ & $107.08+10.00$ & $113.00+5.66$ \\
\hline
\end{tabular}

The value of the observed heterozygosity $(\mathrm{Ho})$ obtained from this study is higher than the value of expected heterozygosity $(\mathrm{He}$ ). Machado et al. (2003) state that if the Ho value is higher than $\mathrm{He}$, it indicates that there has not been an intensive selection of activities using certain males. The result agreed with the report of the Aceh Animal Husbandry Service and the Bogor Agricultural University (2017) stating that in Simeulue buffalo mating still occurs naturally and there has been no selection of superior male and female animals. One of the government programs in improving the genetic quality of Simeulue buffalo in the future is through a superior brood screening program from the community and buffalo nurseries based in Alafan District in 2018 (Aceh Animal Husbandry Service and the Bogor Agricultural University 2017).

\section{The relationship between genotype and body size}

While the AA genotype was only one sample, the relationship between genotype and body size was only possible held in the GHRH/HaeIII gene with $\mathrm{AB}$ and $\mathrm{BB}$ genotypes. In general, the results of the $\mathrm{AB}$ and $\mathrm{BB}$ genotypes in the GHRH/HaeIII gene on body size of buffalo from Alafan, Simeulue Cut and Salang sub-district had no significant different $(p>0.05)$. These results indicate that there is no strong influence on the different genotypes to the body size being analyzed. The lack significant between the genotypes can be due to the nature of cattle growth which is controlled by many genes and can also be influenced by the environment (Ralston and Shaw 2008) so that it does not significantly affect body size. Average body size and error standard $(\mathrm{X} \pm \mathrm{SE})$ on the GHRH/HaeIII locus genotype can be seen in Table 5 .

Diyono et al. (2010) in their work with Banten buffaloes, states that there was no significant relationship between the GHRH/HaeIII gene polymorphism and the body size. Furthermore, research by Sumantri et al. (2011) revealed that polymorphism of the gene found in many cattle, i.e., Angus, Limousin, Brahman, and Simental also no direct link to superovulation response, ovulation rates, percentage rates of fertilization and the percentage of embryos eligible for transfer. Previously, Jakaria and Noor (2011) also reported that there was no significant correlation between $\mathrm{GH} / \mathrm{MspI}$ gene and body size in many cattle such as Coastal, Limousine, and Simmental. However, research by Zhang et al. (2012) showed a relationship between the GHRH gene polymorphism and the production feature of native Chinese cattle which lead the usage the GHRH gene as a potential marker in the selected programs for Chinese cattle breeding. As for Simeulue buffalo, more intensive studies are needed at other genes that regulate their growth properties.

In conclusion, the diversity of body size characteristics among the local buffaloes situated in Simeulue Regency was low. The GH/MspI gene locus in Simeulue buffalo was monomorphic with the presence of one genotype $(+/+)$. The locus of GHRH/HaeIII gene in the buffalo was polymorphic with the appearance of three genotypes, i.e., $\mathrm{AA}, \mathrm{AB}$, and $\mathrm{BB}$ that distributed following Hardy Weinberg's equilibrium. There was no significant relationship between GHRH/HaeIII gene polymorphism and body size characteristics of Simeulue buffalo.

\section{ACKNOWLEDGEMENTS}

The authors wish to thank the Research Institute of Syiah Kuala University, Indonesia and 7 in 1 IDB Project that funded this study under the scheme Penelitian Unggulan Perguruan Tinggi (PUPT) with contract No. 137/UN11.2/PP/SP2/2016.

\section{REFERENCES}

Aceh Animal Husbandry Service and Bogor Agricultural University. 2017. Final Report. Aceh Province Animal Husbandry Development Planning Master Plan. Aceh Province Animal Husbandry Service, Banda Aceh, and Bogor Agricultural University, Bogor. [Indonesian]

Andreas, E, Sumantri C, Nurani H, Farajallah A, Angraini, A. 2010. Identification of GH/alul and GHRH/alul Genes Polymorphisms in Indonesian Buffalo. J Indonesian Trop Anim Agric 35 (4): 215-221.

Carroll SP, Fox CW (eds.). 2008. Conservation Biology: Evolution in Action. Oxford University Press, New York.

Diyono R, Sumantri C, Farajallah A. 2010. Identification of the diversity of GH, GHRH and Pit-1 Genes in the population of Buffalo in Banten. Buffalo Seminar and Workshop. [Indonesian]

Guidry RD, Gahn L. 2012. Modern Clinical Molecular Techniques. Springer, New York.

Handoyo D, Rudiretna A. 2010. General principle and implementation of Polymerase Chain Reaction (PCR). J Unitas 9 (1): 17-29. [Indonesian]

Jakaria R, Noor R, Martojo H, Duryadi D, Tappa B. 2007. Evaluation of The Growth Hormone Genes $(\mathrm{GH})$ in Coastal Cattle in West Sumatra Using RFLP PCR Markers. Med Pet 30 (1): 1-10.

Jakaria, Noor RR. 2011. Analysis on Alu-I Growth Hormone (GHalu1) gene in Bali Cattle. J Indon Trop Anim Agric 36 (2): 77-82.

Konca MA, Akyuz B. 2017. Investigation of growth hormone releasing hormone, growth hormone and prolactin hormone gene polymorphism in Anatolian Water Buffalo. Ann Anim Sci 17 (4): 1053-1062.

Lestari DA, Purbowati E, Sutopo S, Kurnianto E. 2018. Phylogenetical relationships between Kejobong Goat and other goats based on MtDNA D-loop sequence analysis. Trop Anim Sci J 41 (2): 85-93. 
Machado MA, Schuster I, Martinez ML, Campos AL. 2003. Genetic diversity of four breed using microsatellite markers. Rev Bras De Zool 32: 93-98.

Nei M. 1987. Molecular Evolutionary Genetics. Columbia University Press, New York.

Primasari A, Sumantri C, Farajallah A. 2009. Identification of Growth Hormone Releasing Hormone Gene in Local Buffalo (Bubalis bubalus) Using PCR-RFLP. The 1st International Seminar on Anima Industry. Faculty of Animal Science, Bogor Agricultural University, Bogor.

Putra WPB, Hartatik, T, Sumadi. 2014. Growth hormone genotyping by Msp1 restriction enzyme and PCR RFLP method in Aceh cattle breed at Indrapuri District, Aceh Province, Indonesia. Biodiversitas 15: 1-5.

Ralston A, Shaw K. 2008. Environment controls gene expression: sex determination and the onset of genetic disorder. Nature Educat 1 (1): 203.

Ruchlik W, Spencer W.J and Rhoads R.E. 1990. Optimization of the annealing temperature for DNA amplification in vitro. Nucleic Acids Res 18 (21): Oxford University Press.
Sari EM. 2014. Phylogenetic Analisis of Simeulue buffalo breed of Indonesian through mitochondrial D-Loop region. Proceeding the 16 th AAAP Congress. UGM, Yogyakarta.

Sumantri C, Diyono R, Farajallah A, Anggraeni A, Andreas E. 2010. Utilization of the growth hormone family $(\mathrm{GH}, \mathrm{GHR}$, GHRH and PIT-1) to detect the genetic diversity of buffalo in Pandeglang and Lebak District of Banten Province. Jurnal Ilmu Ternak dan Veteriner15: 286-296. [Indonesian]

Suswono. 2014. Establishment of Simeulue Buffalo Family (Clump). Decree of Ministry of Agriculture of The Republic of Indonesia. [Indonesian]

Sutarno. 2010. Genetic variations among Indonesian native cattle breeds based on polymorphisms analysis in the growth hormone loci and mitochondrial DNA. Biodiversitas 11 (1): 1-4

Szatkowska I., Dybus A., Grzesiak W, Jeddrzejczak M, Muzyrisk M. 2009. Association between the growth hormone-releasing hormone (GHRH) gene polymorphism and milk production traits of dairy cattle. J Appl Anim Res 36: 119-123.

Zhang B, Zhao G, Lan X, Lei C, Zhang B, Chen H. 2012. Polymorphism in GHRH and its association with growth traits in Chinese Native Cattle. J Vet Sci 92: 243-246. 